\title{
MANAGING IMPRESSIONS OF RESPONSIBILITY FOR SUCCESS OR FAILURE: MANAGER-SEX AND OBSERVER-SEX EFFECTS
}

Wayne H. Decker, Salisbury State University

Sue Greenfeld, California State University, San Bernardino

\begin{abstract}
College students' responses to fictitious managers' statements concerning responsibility for performance were investigated. Male managers were seen as having greater control than females over productivity. While it was generally best to credit others for success and blame oneself for failure, males (but not females) gave subordinate-crediting managers more favorable ratings than superior-creditors. Males seemed to perceive superior-creditors as self-serving, while females were more apt to take statements at face value.
\end{abstract}

\section{INTRODUCTION}

\section{Self-Presentation and Impression Management}

When organization members interact with others both within and outside their organizations, attempts at impression management are common. Impression management includes manipulation of one's behaviors in order to elicit favorable responses from others (Goffman, 1959). Besides controlling obvious features such as dress and appearance, one can influence impressions through causal self-presentations (i.e., description and explanation of one's accomplishments).

Self-presentation has become a topic of interest to attribution theorists who are concerned with how people perceive and explain the actions of others (Harvey \& Weary, 1984; Weary \& Arkin, 1981). Wood and Mitchell (1981) noted that impression management efforts on the part of subordinates can influence superiors' evaluations of the subordinates. In an empirical study, Giacalone and Riordan (1986) investigated effects of verbal self-presentations upon assessment of managers. They predicted more positive evaluations would be given managers taking credit for an accomplishment and describing personal obstacles overcome than to those attributing success to their subordinates. In other words, more credit would be given managers providing internal explanations of success than to those attributing success to external factors. According to the augmentation principle of attribution theory, behavior which occurs in the face of apparent opposition is viewed as internally caused. The discounting principle holds that the presence of external forces consistent with behavior lessens the attribution of internal causation (Kelley, 1973). Expectations were confirmed as observers awarded more credit to managers claiming responsibility and citing personal obstacles overcome than to those giving credit to subordinates (Giacalone \& Riordan, 1986).

However, the findings of Decker (1987b) were inconsistent with those of Giacalone and Riordan (1986). No self-presentation effects (credit taking vs. credit sharing) were obtained with the questions used in the Giacalone and Riordan (1986) study. It should be noted that accomplishments were described as a team effort in the Decker (1987b) study, while they were more individual in the Giacalone and Riordan (1986) study. Perhaps credit taking was seen as 
unjustified in the former study. Decker (1987b) did find self-presentation to influence responses to other items, but credit-sharing managers were evaluated more positively than credit takers. Managers sharing credit were viewed more favorably with respect to modesty and desirability as supervisors than managers crediting themselves. Similarly, Tetlock (1980) found teachers refusing credit for students' success (or assuming responsibility for failure) were rated more favorably than teachers taking credit (or denying responsibility for failure). Furthermore, Decker (1987a, 1988) obtained results largely consistent with those of Tetlock (1980). Managers were rated more favorably when crediting others or blaming themselves than crediting themselves or blaming others. However, crediting superiors did not yield ratings as high as did crediting subordinates.

While taking credit for success may be a means of providing causal information, it may also be perceived as self-serving. Likewise, superior-crediting may be viewed as self-serving (Decker, 1987a, 1988). Walster, Aronson, and Abrahams (1966) and Mills and Jellison (1967) found communicators arguing in a self-serving manner were less persuasive than those arguing against their own self-interest. A person's statements may not be convincing when he/she stands to gain from crediting or blaming.

\section{Sex Differences}

The fictitious managers rated in the Decker (1987a, 1988) studies were male. Female managers' self-presentations may be judged by different standards than are males'. For example, Deaux and Emswiller (1974) and Feldman-Summers and Kiesler (1974) noted women's success is often attributed to luck rather than to ability. Similarly, Giacalone and Riordan (1986) suggested women are perceived as having less ability than equally successful men, but as putting forth greater effort. Empirical results include the fact that accomplishments of managers citing obstacles to performance were rated more difficult for women than for men, but men more than women were seen as deserving of recognition (Giacalone \& Riordan, 1986). Females enrolled in an Australian secondary school awarded personal credit for success to males more than females, while they assigned more blame for failure to females than males (Feather \&
Simon, 1975). In fact, females were generally evaluated more positively if they failed than if they succeeded, whether the occupation was medicine, nursing, or teaching. Perhaps males are viewed as more in control and engaging in more sex-appropriate behavior (at least when success occurs) and, therefore, more deserving of credit for success. Female managers, on the other hand, may be expected to give more credit to others for success (which for them is not due to ability) and to accept more blame for failure (which is due to lack of ability).

Given women's changing roles in the work force and in society in general, observers may have varying expectations about how a woman manager would or should act in terms of giving credit or dispensing blame, but similar expectations about how a male manager would or should act. Observers holding traditional stereotypes may view women managers more negatively than do observers who make fewer behavioral distinctions between sexes. It seems that males would be more likely than females to be in the former category, although certainly some females would as well (Feather \& Simon, 1975).

Thus, the purpose of this study was to investigate reactions to self-presentations as a function of manager sex and observer sex. Hypotheses were: 1) Female managers would be viewed less favorably than would male managers. They would be perceived as less responsible for success, but more responsible for failure. 2) Managing would be perceived as more difficult for females. Females would be perceived as having less control than males over productivity. 3) Self-crediting by females would be viewed as more unusual and less advisable than that by males. 4) Self-blame by females would be perceived as less unusual and more advisable than that by males. 5) Females would rate female managers more favorably than would males, while the sexes would respond similarly to male managers.

\section{METHOD}

\section{Design}

A male or female plant manager was evaluated after assigning credit for success or blame for failure to himself/herself, subordinates or superiors. The design included all possible combina- 
tions of manager sex, success or failure, person(s) held responsible (self, subordinates, or superiors), and observer (respondent) sex (a $2 \mathrm{x}$ $2 \times 3 \times 2$ factorial design).

\section{Respondents}

The respondents were 260 students, 144 males and 116 females, enrolled in management courses at a state university. One hundred eighty-six were employed, 72 full time and 114 part time. Fifty-one reported being managers.

\section{Procedure}

Respondents were assigned to treatments by block randomization. Each respondent read a vignette beginning with background information on George/Marge Morton, an electronics plant manager. George/Marge was being interviewed by the press concerning the plant's recent productivity improvements/declines. The manager was quoted as directing credit or blame to himself/herself, subordinates, or superiors.

Respondents completed ten, 7-point rating scales which had the ends labeled. They judged such factors as the accuracy of George's/Marge's remarks, whether the manager believed his/her statements, his/her responsibility for the plant's performance, whether he/she looked out more for himself/herself or others, whether he/she deserved to keep his/her job, and the desirability of working for a manager like George/Marge.

\section{RESULTS}

For all statistical tests, probability levels of .05 or lower were considered statistically significant. For all analyses of variance, degrees of freedom $=1,236$. A $2 \times 2 \times 3 \times 2$ analysis of variance revealed one item, "control over productivity," having a significant manager-sex main effect. Means were 4.72 and 4.20 for males and females, respectively. On other questions, observers judged male and female managers very similarly. This provides only partial support for Hypothesis 2 and no support for Hypotheses 1,3 , or 4 that significant managersex differences would occur.

The means for the six blaming condition-observer sex combinations are presented in Table
1. Generally, blaming oneself was perceived more favorably than blaming others regardless of the manager's or observer's sex. Pair comparisons of the self- and subordinate-blaming conditions yielded six significant differences for male respondents and four for females (Duncan's Multiple Range Test). Comparisons of self- and superior-blaming yielded three significant differences for each respondent sex. Little difference occurred between the subordinate-blaming and superior-blaming conditions. Comparisons of the subordinate-blaming and superior-blaming conditions yielded one significant difference for male respondents and none for females. Males, but not females, viewed the superior-blaming manager more desirable to work for than the subordinate-blaming manager.

The means for the six crediting conditionobserver sex combinations are presented in Table 2. Paired comparisons of subordinate- and superior-crediting yielded significant differences on six items for males and none for females. The subordinate-creditor was judged by males as looking out more for others, more accurate in interpreting the events, believing his/her own statements more, wiser in making the statements, more deserving of keeping his/her job, and more desirable to work for.

Subordinate-crediting managers were judged more favorably than the self-creditors on five items by males and four by females. Comparisons of superior-and self-creditors yielded one significant difference for males and three for females. Both males and females judged superior-creditors as believing their statements less, while only females judged superior-creditors as looking out more for others and making more advisable statements.

Direct comparisons of male vs. female observers were obtained by simple main effects analyses of observer-sex differences within the six combinations of the credit or blame and attribution-object (self, subordinates, or superiors) variables. These indicated significance on five items within the superior-crediting condition. (The other five combinations each yielded significance on no more than one item.) Females, in contrast to males, rated the superior-creditor higher on job difficulty, looking out for others, believing his/her statements, advisability of making the statements, and desirability to work for. 
Table 1

Blaming-Condition Means

\begin{tabular}{|c|c|c|c|c|c|c|c|}
\hline \multirow[b]{2}{*}{ Item } & \multicolumn{3}{|c|}{ Male Observers } & \multicolumn{4}{|c|}{ Female Observers } \\
\hline & Subord. & Super. & Self & & Subord. & Super. & Self \\
\hline \multicolumn{8}{|l|}{ Job } \\
\hline $\begin{array}{l}\text { Difficulty } \\
\text { Looking Out }\end{array}$ & $4.96 a$ & $5.16 a$ & $5.14 a$ & $:$ & $4.94 a$ & $5.32 a$ & $5.00 a$ \\
\hline $\begin{array}{c}\text { For Others } \\
\text { Responsibility }\end{array}$ & $2.11 \mathrm{a}$ & $2.44 \mathrm{a}$ & $4.43 \mathrm{~b}$ & $:$ & $1.89 a$ & $2.26 a$ & $4.95 b$ \\
\hline For Results & $5.32 a$ & $4.84 a b$ & $4.62 b$ & : & $5.33 a$ & $5.11 a$ & $4.81 a$ \\
\hline Accuracy of & & & & : & & & \\
\hline $\begin{array}{l}\text { Interpretation } \\
\text { Deserving To }\end{array}$ & $2.79 a$ & $3.60 a$ & $3.19 a$ & $\begin{array}{l}: \\
:\end{array}$ & $2.78 a$ & $3.05 a$ & $2.71 a$ \\
\hline Keep Job & $3.21 a$ & $3.64 \mathrm{ab}$ & $4.33 b$ & : & $3.39 a$ & $3.79 a$ & $4.81 b$ \\
\hline Remarks & & & & : & & & \\
\hline $\begin{array}{l}\text { Unusual } \\
\text { Believed Own }\end{array}$ & $4.07 a$ & $3.60 \mathrm{a}$ & $4.24 \mathrm{a}$ & : & $4.39 a$ & $4.42 a$ & $5.71 \mathrm{~b}$ \\
\hline $\begin{array}{r}\text { Statements } \\
\text { Advisable To }\end{array}$ & $4.46 a$ & $4.96 a$ & $4.67 a$ & $:$ & $4.06 a$ & $4.32 a$ & $4.10 a$ \\
\hline $\begin{array}{l}\text { Have Said } \\
\text { Control Over }\end{array}$ & $1.93 \mathrm{a}$ & $2.12 a$ & $3.00 \mathrm{~b}$ & $:$ & $2.06 a$ & $2.11 a$ & $2.10 \mathrm{a}$ \\
\hline $\begin{array}{l}\text { Productivity } \\
\text { Desirable To }\end{array}$ & $4.89 a$ & $4.60 \mathrm{ab}$ & $3.90 \mathrm{~b}$ & $:$ & $4.28 a$ & $4.58 a$ & $4.38 a$ \\
\hline Work For & $1.79 \mathrm{a}$ & $2.56 \mathrm{~b}$ & $4.14 \mathrm{C}$ & : & $2.22 \mathrm{a}$ & $2.53 \mathrm{ab}$ & $3.33 \mathrm{~b}$ \\
\hline
\end{tabular}

Table 2

Crediting-Condition Means

\begin{tabular}{|c|c|c|c|c|c|c|c|}
\hline \multirow[b]{2}{*}{ Item } & \multicolumn{3}{|c|}{ Male Observers } & \multicolumn{4}{|c|}{ Female Observers } \\
\hline & Subord. & Super. & Self & & Subord. & Super. & Self \\
\hline \multicolumn{8}{|l|}{ Job } \\
\hline $\begin{array}{l}\text { Difficulty } \\
\text { Looking Out }\end{array}$ & $4.55 a$ & $3.96 a$ & $4.29 a$ & $:$ & $5.05 a$ & $5.22 a$ & $4.84 a$ \\
\hline $\begin{array}{l}\text { For Others } \\
\text { Responsibility }\end{array}$ & $4.86 a$ & $3.63 b$ & $3.21 b$ & $:$ & $4.71 \mathrm{a}$ & $4.83 a$ & $3.11 \mathrm{~b}$ \\
\hline $\begin{array}{l}\text { For Results } \\
\text { Accuracy of }\end{array}$ & $5.00 \mathrm{a}$ & $4.38 a$ & $4.75 a$ & $:$ & $4.86 a$ & $4.78 a$ & $4.47 a$ \\
\hline $\begin{array}{l}\text { Interpretation } \\
\text { Deserving To }\end{array}$ & $4.18 a$ & $3.33 b$ & $3.13 \mathrm{~b}$ & $:$ & $4.81 \mathrm{a}$ & $3.89 \mathrm{a}$ & $3.79 a$ \\
\hline $\begin{array}{l}\text { Keep Job } \\
\text { Remarks }\end{array}$ & $5.95 a$ & $5.08 b$ & $5.08 \mathrm{~b}$ & $:$ & $6.05 a$ & $5.56 a$ & $5.47 a$ \\
\hline $\begin{array}{c}\text { Unusual } \\
\text { Believed Own }\end{array}$ & $3.27 \mathrm{a}$ & $4.04 a$ & $3.92 a$ & $:$ & $3.10 \mathrm{a}$ & $3.06 a$ & $3.16 a$ \\
\hline $\begin{array}{l}\text { Statements } \\
\text { Advisable To }\end{array}$ & $4.55 a$ & $3.04 \mathrm{~b}$ & $5.00 \mathrm{a}$ & $:$ & $4.81 \mathrm{a}$ & $4.39 a$ & $6.11 b$ \\
\hline $\begin{array}{l}\text { Have Said } \\
\text { Control Over }\end{array}$ & $5.27 a$ & $3.79 \mathrm{~b}$ & $2.83 b$ & $:$ & $5.57 a$ & $5.00 a$ & $3.37 \mathrm{~b}$ \\
\hline $\begin{array}{l}\text { Productivity } \\
\text { Desirable To }\end{array}$ & $4.45 a$ & $4.25 a$ & $4.21 a$ & : & $5.05 a$ & $4.78 \mathrm{a}$ & $4.21 a$ \\
\hline Work For & $4.64 \mathrm{a}$ & $2.75 b$ & $2.75 b$ & : & $4.95 a$ & $4.06 \mathrm{ab}$ & $3.53 \mathrm{~b}$ \\
\hline
\end{tabular}




\section{DISCUSSION}

Only one predicted manager-sex difference was obtained (viz., that female managers were perceived as having less control over productivity). This may imply: 1) sex-stereotyping of managerial behavior is minimal, or 2) the female plant manager was not viewed as a typical female. That sex-stereotyping is minimal, at least within some occupations, was reported by Hesselbart (1977). She obtained no differences between perceptions of male and female college professors' performance in four academic fields. However, Schein (1975) conducted a study of stereotypes in which respondents rated the stimulus objects: "men," "women," and "successful managers" (sex not specified). Men were rated higher than females and more similar to successful managers than were females on such dimensions as self-confidence, ambition, and ability to lead. Arkkelin and Simmons (1985) maintained that it was not surprising that successful managers would be described in masculine terms. Since the profession is dominated by men, chances are most respondents assumed that "successful managers" were men. It does not mean that women mangers must be like men to be successful. Arkkelin and Simmons (1985) asked respondents to rate the desirability of traits attributed to fictitious managers. Their results seemed to imply that managers should display some qualities from each of the traditional sex stereotypes. For example, assertiveness and competitiveness (masculine) as well as being understanding and loyal (feminine) were among the highest rated traits. The extent sex-stereotypes put females at a disadvantage in the business world requires further investigation. In regard to the second point above, Hesselbart (1977) has previously suggested that females who successfully compete with males may be considered by persons holding sex-stereotypes to be exceptions to the rule, allowing the stereotypes to remain intact despite evidence to the contrary. These females are perceived to have characteristics different than and often superior to typical females.

More striking than manager-sex differences in this study were indications males and females judged managers differently. Females seemed to accept superior-crediting managers' statements at face value, while males were more critical of superior-crediting behavior. Perhaps the use of smaller samples than those of the present study was responsible for the lack of respondent-sex differences obtained by Decker (1987a). Possible explanations for males' downgrading superior-crediting managers include: 1) more experiences with the realities of the working world, 2) more work experiences in settings where selfserving self-presentations occur, or 3) males may be socialized to have greater suspicions of other persons' motives. The first alternative seems unlikely since the present sample contained a greater percentage of females than males over 25 years of age (by a margin of $6 \%$ ) and greater percentage of males than females under 21 (by a margin of $8.5 \%$ ). A higher percentage of females were managers (a difference of less than $1 \%$ ), but a greater percentage of males were working full time at the time of the study (a difference of less than 2\%). (Data concerning prior work history were not obtained.) The present study provides no insights concerning the second and third alternatives above. Future investigations should include populations other than students to test the generality of these results.

The lack of differences between ratings of subordinate- and superior-blamers supports the notion that differences between crediting conditions in the Decker (1987a) study and for male observers in the present study were not merely due to observers being biased in favor of subordinates, but were due to greater self-service intent being attributed to superior-creditors. It seems observers merely biased in favor of subordinates would judge subordinate-blamers more harshly than superior-blamers. Perhaps both subordinate- and superior-blamers were viewed as highly self-serving. Presumably then, selfblamers were judged more favorably than other managers associated with poor performance due to the lack of self-service on their part. Results of the "looking out for others" item seem to bear this out. In addition, self-blamers may have benefitted from the implication that the source of the problem was now recognized and performance would be improved in the future (Wood \& Mitchell, 1981).

In conclusion, despite the observer-sex differences obtained, both males and females rated subordinate-crediting and self-blaming managers as the most desirable to work for, regardless of the managers' sexes. In addition, females did 
not seem to mind having superior-crediting bosses. While crediting and blaming behaviors were studied in an isolated situation, in real situations they occur in the context of other information. A basic tenet of attribution theory is the consistency principle (Kelley, 1973). Behaviors consistent with other behaviors by an actor are seen as more reflective of the actor's true nature than those behaviors that are inconsistent. Wood and Mitchell (1981) maintain additional information consistent with the performance being evaluated will lead to discounting of conflicting impression management attempts. Similarly, Giacalone (1985) found another authority's statements in opposition to an actor's selfpresentation lessened the influence of the latter. In addition, credit received from a co-worker influenced observers' impressions more positively than did self-crediting. Therefore, persons attempting impression management techniques, such as crediting others or blaming themselves need to keep in mind the forces which may counteract their efforts.

\section{FOOTNOTES}

\section{Support was received from the Franklin P. Perdue Fund, Salisbury State University Foundation.}

\section{REFERENCES}

1. Arkkelin, D., \& Simmons, R. (1985). The "good manager": Sex-typed, androgenous, or likable? Sex Roles, 12, $1187-1198$.

2. Deaux, K., \& Emswiller, T. (1974). Explanation of successful performance on sex-linked tasks: What is skill for the male is luck for the female. Journal of Personality and Social Psychology, 29, 80-85.

3. Decker, W. H. (1987a). Attributions as a function of managers' assignment of credit to self, superiors, or subordinates. Psychological Reports, 61, 897-898.

4. Decker, W. H. (1987b). Attributions based on managers' self-presentation, sex, and weight. Psychological Reports, 61, $175-181$.

5. Decker, W. H. (1988). Attributions as a function of managers' assignment of blame to self, superiors, or subordinates. Perceptual and Motor Skills, 66, 318.

6. Feather, N. T., \& Simon, J. G. (1975). Reactions to male and female success and failure in sex-linked occupations: Impressions of personality, causal attributions, and perceived likelihood of different consequences. Journal of Personality and Social Psychology, 31, 20-31.

7. Feldman-Summers, S., \& Kiesler, S. B. (1974). Those who are number two try harder: The effect of sex on the attribution of causality. Journal of Personality and Social Psychology, 30, 846-855.

8. Giacalone, R. (1985). On slipping when you thought you had put your best foot forward: Self-promotion, self-destruction, and entitlements. Group and Organization Studies, 10, 61-80.

9. Giacalone, R. \& Riordan, C. A. (1986). Effects of self-presentation on perceptions in an organization. Proceedings of the Academy of Management, Southwest Division, pp. 91-95.

10. Goffman, E. (1959). The presentation of self in everyday life. New York: Doubleday Anchor.

11. Harvey, J. H., \& Weary, G. (1984). Current issues in attribution theory and research. In M. R. Rosenzweig \& L. W. Porter (Eds.), Annual review of psychology (Vol. 35, pp. 427-459). Palo Alto, Calif: Annual Reviews, Inc.

Hesselbart, S. (1977). Sex role and occupational stereotypes: Three studies of impression formation. Sex Roles, 3, 409-422.

Kelley, H. H. (1973). The processes of causal attribution. American Psychologist, 28, 107-128.

Mills, J., \& Jellison, J. M. (1967). Effect on opinion change of how desirable the communication is to the audience the communicator addressed. Journal of Personality and Social Psychology, 6, 98-101.

15. Schein, V. E. (1975). Relationships between sex-role stereotypes and requisite management characteristics among female managers. Journal of Applied Psychology, 60, 340-344.

16. Tetlock, P. E. (1980). Explaining teacher explanations of pupil performance: A self-presentation interpretation. Social Psychology Quarterly, 43, 283-290.

17. Walster, E., Aronson, E., \& Abrahams, D. (1966). On increasing the persuasiveness of a low prestige communicator. Journal of Experimental Social Psychology, 2, 325-343.

18. Weary, G., \& Arkin, R. M. (1981). Attributional self-presentation. In J. H. Harvey, W. Ickes, \& R. F. Kidd (Eds.), New directions in attributional research (Vol. 3, pp. 223-246). Hillsdale, N.J.: Erlbaum.

19. Wood, R. E., \& Mitchell, T. R. (1981). Manager behavior in a social context: the impact of impression management on attributions and disciplinary actions. Organizational Behavior and Human Performance, 28, 356-378. 